
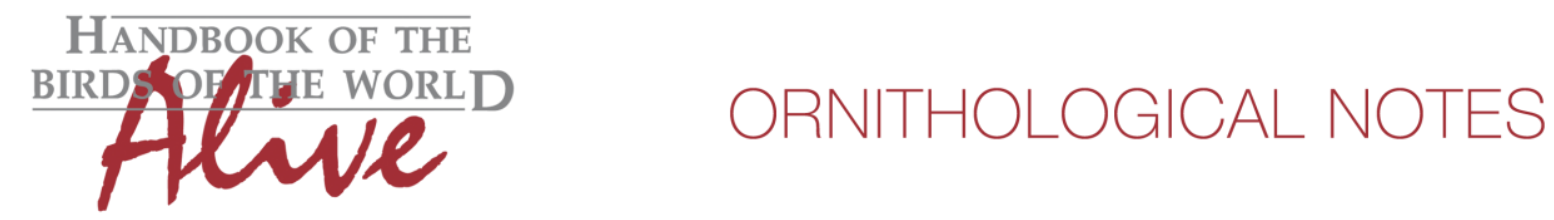

\title{
Notes on the vocalizations of Necklaced Spinetail (Synallaxis stictothorax)
}

Peter Boesman

In the following we briefly analyze and compare voice of the different races of Necklaced Spinetail (Synallaxis stictothorax). We also try to quantify the extent of any vocal differences using the criteria proposed by Tobias et al. (2010), as a support for taxonomic review. We have made use of sound recordings available on-line from Xeno Canto (XC).

There seems to be a considerable difference in voice, with three identifiable groups. Within groups, there is some variation depending on the level of excitement, delivery of short or extensive song, response by partner in duet or not, recordings after playback, etc. Making abstraction of this variation, the song is as follows:

maculata and stictothorax $(n=7)$

Song is a series of 2-5 short notes (0.023-0.03s, downslurred from c. 2500 to $1200 \mathrm{~Hz}$ ) seamlessly switching into a series of $2-3$ overslurred notes $(0.04 \mathrm{~s}, 1100-3500 \mathrm{~Hz})$ with longer pauses in between and culminating into 2-5 bisyllabic notes (0.1-0.12s) 'ku-eet...ku-eet' with a characteristic note shape. Sometimes ending symmetrically with similar notes as in the beginning (possible of partner in duet). Stictothorax seems to have on average less notes than maculata, but structure and shape identical.

chinchipensis $(n=5)$

Song is a rattling series of $4-6$ short notes $(0.018-0.025 \mathrm{~s}, 1200-1600 \mathrm{~Hz})$ followed by a fairly long pause (0.16-0.20s) before giving a single emphasized note (c. $0.075 \mathrm{~s}, 1350-4200 \mathrm{~Hz}$ range) with a characteristic note shape, which then is followed by a loud rattling series of 5-7 notes (downslurred, $1100-3500 \mathrm{~Hz}$ range). Sometimes followed by a long stuttering series of short downslurred notes (presumably of partner in duet).

undescribed southern coastal race $(n=3)$

Song is a long rattling series of notes ( 50 or more notes, with often both birds of a pair singing together, delivering a 'double rattle'), without much change in shape of notes or other pattern. All notes short and overslurred (c. $0.25 \mathrm{~s}$ ). No long pauses in between, no long emphasized notes. Sometimes rattle starts with a few more spaced notes.

All songs are thus easily identified (Fig. 1). 


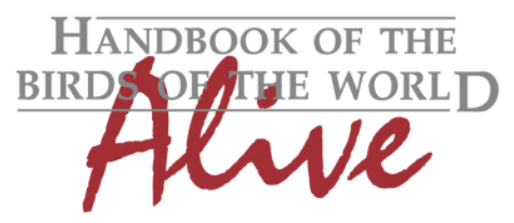

\section{ORNITHOLOGICAL NOTES}
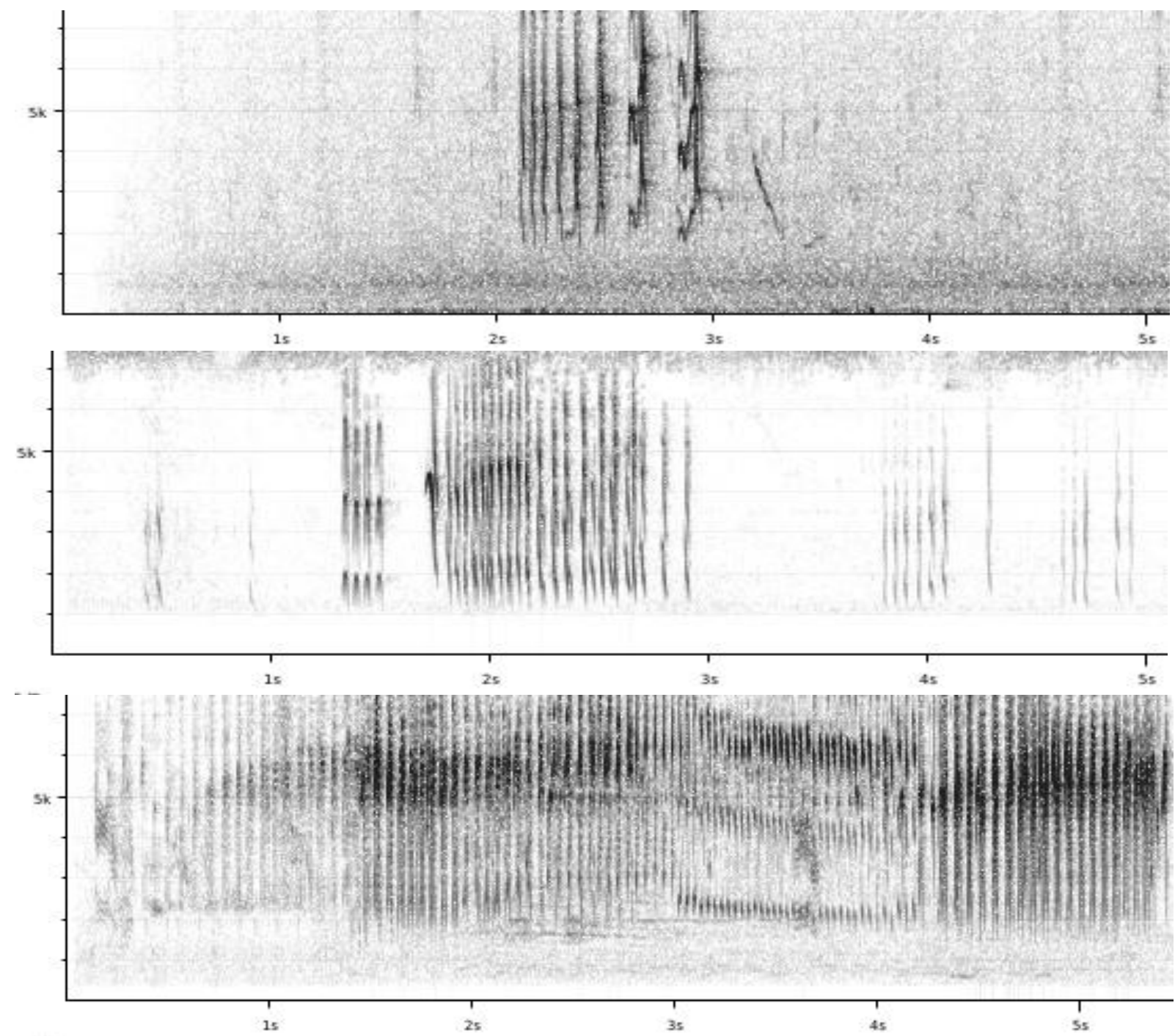

Figure 1: typical song of maculata/stictothorax(top), chinchipensis (middle) and undescribed southern race (bottom)

Quantified differences :

Undescribed form vs both other groups: number of notes in song phrase is much higher (3) and length of longest note much shorter (3). This would lead to a total vocal score of 6 when applying Tobias criteria.

chinchipensis versus 'maculata and stictothora': number of long notes in song lower (3), length of the longest note shorter (2) and length of longest pause in song phrase longer (2). This would lead to a total vocal score of 5 when applying Tobias criteria. 
This note was finalized on 13th April 2015, using sound recordings available on-line at that moment. We would like to thank in particular the sound recordists who placed their recordings for this species on XC: Roger Ahlman, Peter Boesman, Paul Coopmans, David Edwards, Jon Hornbuckle, Niels Krabbe, Frank Lambert, Dan Lane, Mitch Lysinger, Hans Matheve, John V Moore, Leonardo Ordoñez-Delgado, Andrew Spencer.

\section{References}

Tobias, J.A., Seddon, N., Spottiswoode, C.N., Pilgrim, J.D., Fishpool, L.D.C. \& Collar, N.J. (2010). Quantitative criteria for species delimitation. Ibis 152(4): 724-746.

\section{Recommended citation}

Boesman, P. (2016). Notes on the vocalizations of Necklaced Spinetail (Synallaxis stictothorax). HBW Alive Ornithological Note 104. In: Handbook of the Birds of the World Alive. Lynx Edicions, Barcelona. (retrieved from http://www.hbw.com/node/932009 on 23 July 2016). 